\title{
Study on the Woodblock New Year Pictures of Zhuxianzhen Town*
}

\author{
Hong Nie \\ School of Art and Design \\ Wuhan University of Science and Technology \\ Wuhan, China 430065
}

\author{
Mengyao Ran \\ School of Art and Design \\ Wuhan University of Science and Technology \\ Wuhan, China 430065
}

\begin{abstract}
Zhuxianzhen woodblock New Year Picture has a long history and is the leading and source of Chinese woodblock New year Pictures, which is the living fossil of Chinese Folk Wood New year Pictures. Zhuxianzhen's woodblock New Year Pictures originated from the Han and Tang murals, evolved from ancient peach symbols, exuberance in the Song Dynasty, flourished in the Ming and Qing dynasties, declined in the Republic of China, and prosper in the contemporary era. It has unique characteristics of cultural symbols, its artistic image is simple and exaggerated, its color is beautiful and auspicious, its expressive technique is romantic, and it has extremely high ornamental value and art collection value. This paper analyzes the visual language features of Zhuxianzhen woodblock pictures from the aspects of modeling features, composition features and color features of the New Year Pictures, and compares them with those of other places, in order to explore the profound cultural connotation and religious implication of Zhuxianzhen woodcut New Year picture.
\end{abstract}

Keywords-Zhuxianzhen; woodcut new year pictures; image; visual language

\section{INTRODUCTION}

The folk woodcut New Year picture is an important art category in the folk art of our country, Its performance content from the early natural worship and deity belief, gradually developed into exorcism, pray for disaster and happy festival custom activities Zhuxianzhen woodblock New year pictures have a variety of themes, which can be divided into five categories: door gods, horses of gods, opera and legendary stories, family hall and game pictures, it's mainly the door gods, The themes of the idol in the image comes from gods of Buddhism, Taoism, Confucianism and folk gods, industry ancestors, folklore, mythology stories, doll zodiac and so on.

The word "door god" first appeared in "Li Ji, Sang Fu Da Ji”, The term "New Year Pictures" first appeared in the book "Xiang Yan Jie Yi" in Daoguang period, which in essence is an idealistic picture. The posting of New Year Pictures has

*Fund projects: This paper is the periodical achievement of the provincial teaching research project of Hubei Province in 2017 "Research on practical Teaching Mode of Visual Communication Design based on Community Service" (Project No. 2017245); Stage achievement of the research on Urban Color Culture based on GIS platform in the General Research Project of Humanities and Social Sciences of the Education Department of Hubei Province in 2018: a case study of Wuhan City Center (Project number 18Y029). strict time, place, and the specific position and content of posting regulations. It is one of the folklore acts to post the New Year Pictures in the specified position at a specific time.

\section{THE PRESENT SitUATION OF THE RESEARCH ON WOODCUT NEW YEAR PICTURES IN ZHUXIANZHEN}

Chinese picture is generally divided into court picture, literati picture, religious picture and folk picture. Folk woodcut New Year picture is a kind of picture style in folk picture. As a unique artistic style of Chinese folk picture, woodcut New Year pictures had appeared in Han Dynasty, with profound cultural background. Zhuxianzhen in Kaifeng, Henan Province is the birthplace of Chinese Gods and Chinese New year couplets, which contains the history and profound cultural connotation of Chinese woodcut New Year pictures for nearly a thousand years, and has a high research value. Zhuxianzhen woodblock New Year picture is different from the exquisite and delicate court pictures, but also quite different from the dizzy painted New Year pictures in other places. It has a simple atmosphere, bright colors and no vulgar characters, so it is a unique artistic style of the Northern New Year pictures. It is worth studying. At present, under the voice of protecting and inheriting the intangible cultural heritage, more and more researchers have a sense of identity and mission to the intangible cultural heritage passed down from generation to generation. As an intangible cultural heritage, Zhuxianzhen woodblock New Year Picture has unprecedented opportunities to inherit and spread.

\section{VisuAl LANGUAGE FEATURES OF WOODCUT NEW YEAR PICTURES IN ZHUXIANZHEN}

Chinese New Year pictures originated from the totem worship and religious belief of people in ancient times, were conceived in the developing Han and Tang culture, formed in the prosperous market life of the Song Dynasty, and flourished in the folk of the Qing Dynasty. Zhuxianzhen woodblock New Year Pictures have unique style, full composition, exaggerated modeling, rough lines, bright colors, and character modeling has unobtrusive state, which have the unique artistic characteristics of the northern nation. 


\section{A. Character Image Modeling Feature of Zhuxianzhen's Woodcut New Year Pictures}

With the passage of time, the modeling of New Year Pictures also changed, and the art of New Year Pictures also changed from simple and plain to rich. In the Eastern Han Dynasty, Cai Yi's "Dictatorial" contains the information about the tiger's picture and (Shenshu and Yulu) gods' picture on the door in the folk; both the Shanhai Classics cited from Wang Chong's "Lun Heng" and Ying Shao’s "Fengsu Tongyi" have the records of Shenshu and Yulu.

The door image of stone portrait brick unearthed from Han tombs in Mixian County, Henan Province, there is the archetypal image of Shenshu, Yulu holding a tiger. This modeling comes from folk legend about Shenshu, Yulu catching ghosts that hurt persons to feed tigers, the figure wears a Han suit and a high crown. The figure modeling is carved on a stone with a rough and powerful line, which creates an environment with thread, which shows the simple beauty of "Though it is artificial, it is as if it were made of heaven."Han Tomb in Nanyang, Henan Province unearthed Shenshu, Yulu holding an axe, handheld combat weapon-the left with wood stick, the right with an axe, the face is fierce, the figure is abstract and exaggerated, extremely personality, which has a deterrent effect, "Fig. 1". These two door-picture images are highly summarized and highly simplified, unity of form and spirit, making the overall image have a momentum of majestic. Influenced by the art of Buddhist grottoes in Sui and Tang dynasties, the gate picture presented auspicious features, the characters tended to realistic style, the facial expressions were rich in charm, and character posture was influenced by the robust posture of the Tang Dynasty at that time, character shape is honest and thick. Shenshu, Yule holding hammers in his hands, armored, wearing official hats, with battlefield warrior spirit, "Fig. 2".
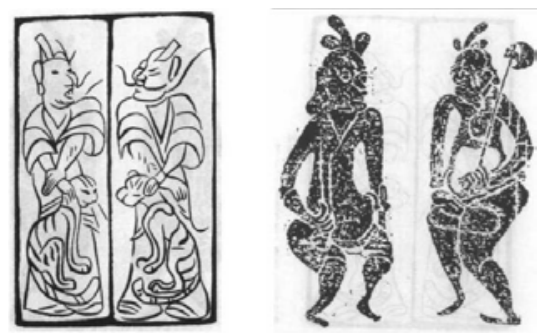

Fig. 1. Shenshu and Yulu with axe; Time: Han Dynasty.

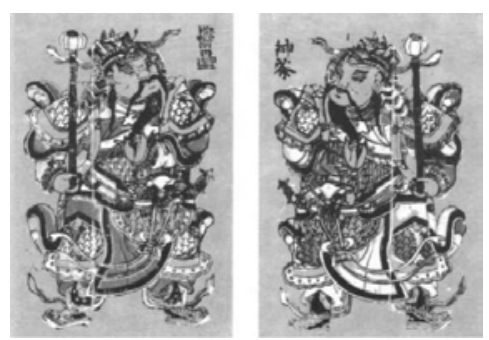

Fig. 2. Shenshu and Yulu with axe; Time: Han and Tang dynasties.

During the Sui and Tang dynasties, Taizong Li Shimin was haunted in the middle of the night, sending Qin Qiong and Wei Chigong to stand guard. Later, the picture master painted two people attached to the palace on the town house, later this form spread in the folk. "a complete collection of the Source and flow of the three religions search for gods" Scroll 7 In the postscript of the image of the door god two general picture , there is a record of the image of the two god holding a jade axe, waist whip mace, bow and arrow, "Fig. 3". Qin Qiong and Wei Chigong had different style and clothes in different periods, comparatively speaking, Qin Qiong, Wei Zhigong in the woodblock New Year Pictures of Zhuxianzhen in the Qing Dynasty, had more diversified shapes, more exaggerated figures, and more artistic and intimidating characters in which facial expressions were incorporated into the opera. The weapons in the hands of the characters are also more diversified, from holding a jade axe to becoming a gold mace, a steel whip, a weapon, and a change in the shape of the character. The shape of the character has also changed. Styling is divided into: whip under step, horse whip, back whip, holding whip, vertical knife, robes and other styles, "Fig. 4", "Fig. 5”, "Fig. 6” and "Fig. 7”.

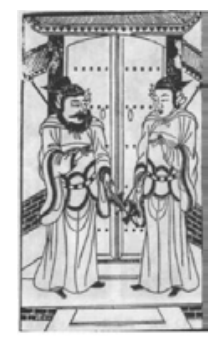

Fig. 3. Qinshubao, Yuchigong; Time: Ming Dynasty.

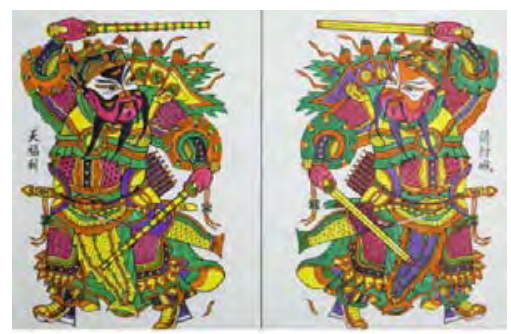

Fig. 4. Qinqiong, Yuchigong; Time: Qing Dynasty.

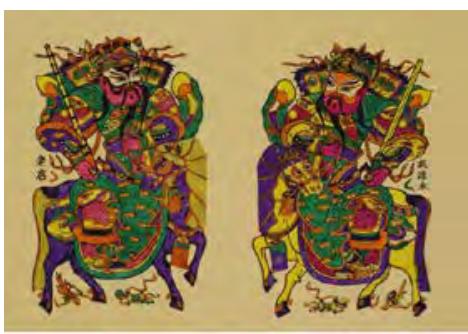

Fig. 5. Qinqiong, Yuchigong; Time: Qing Dynasty. 


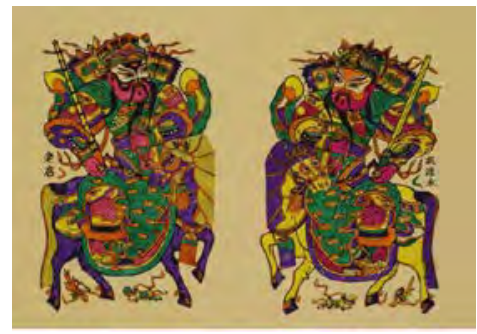

Fig. 6. Qinqiong, Yuchigong; Time: Qing Dynasty.

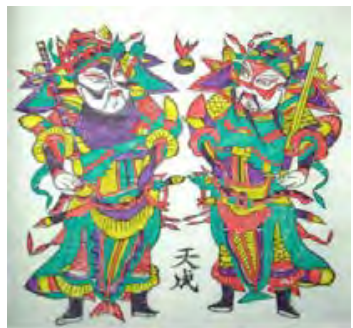

Fig. 7. Qinqiong, Yuchigong; Time: Qing Dynasty.

From the time to the Tang Dynasty, Tang Xuanzong dreamed of Zhong Kui eating hungry ghost, and ordered Wu Daozi to draw an image of Zhong Kui in order to keep the town safe. Zhuxianzhen woodblock New year picture Zhong Kui is divided into Dakui head, Xiaokui head, the whole body like three kinds of images, "Fig. 8”, "Fig. 9" and "Fig. 10", Dakui head face fangs, his right hand with a pen, the left hand tightly grasp the book, wearing official ha on head t, lion nose ring eye, prickly beard; XiaoKui head is similar to Dakui head, and his face is milder than Daguitou's; Zhong Kui sat as if to embrace the control evil sword, short bouquet dress, ring eyes angry, powerful and ferocious.

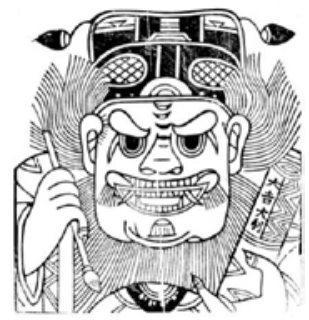

Fig. 8. Dakui head; Time: Qing Dynasty.

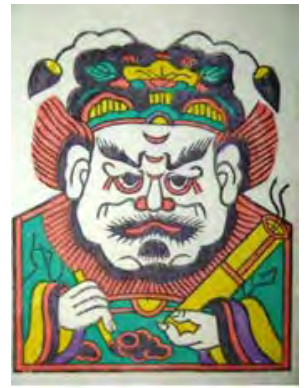

Fig. 9. Xiaokui head; Time: Qing Dynasty.

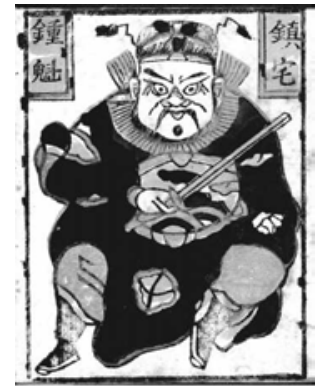

Fig. 10. Zhongkui; Time: Qing Dynasty.

The stove picture is used by the kitchen god in the house, and put the statue of the Kitchen on the wall of the earthen cooker, hoping that the god of the stove would "say good things from heaven, and keep the lower boundary safe." The traditional architecture and the axis symmetry in shrine are used to compose the picture of Kitchen god, arrange the characters in the cooker picture in order and make a clever combination. In the earlier New Year pictures, the king of the stove was gentle and kind, wearing a crown and a red robe, sitting in the center of the picture. Later, the character of queen of stove was added to the New Year Pictures, with a fine look, a phoenix crown on her head and a green robe. The treasure basin and the rich tree were painted before the queen of the cooker and the king of the stove, in order to achieve people's blessing of the rich and the prosperity of peace and prosperity, "Fig. 11".

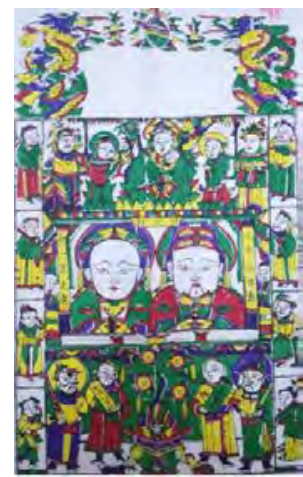

Fig. 11 . Kitchen God; Size: $44 \mathrm{~cm} \times 28 \mathrm{~cm}$.

Praying for blessings and recruiting money as door god modeling including Wenwu god of wealth and Wenmen god ( praying for blessings door god, Samsung door god, boy door god, fortune god, The celestial god sent the subspecies, drama and story legend god) The shapes of their characters come from mythology and folklore. The characters are mostly small with large heads and exaggerated proportions. The decorative patterns in the pictures are homophonic and meaningful, which reflect people's desire for a happy family life and live and work in peace and contentment, "Fig. 12", "Fig. 13" and "Fig. $14 "$. 


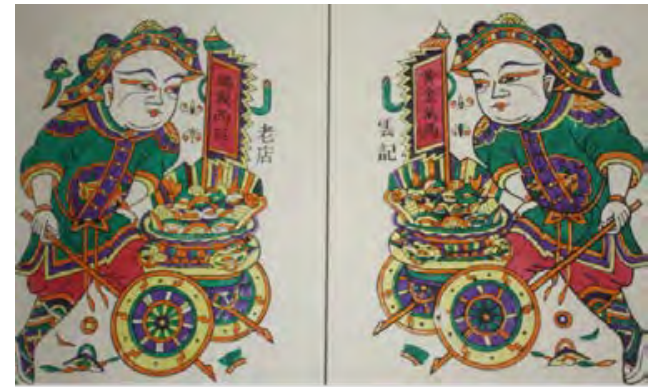

Fig. 12. Chai King pushing a cart; Size: $60 \mathrm{~cm} \times 40 \mathrm{~cm}$.

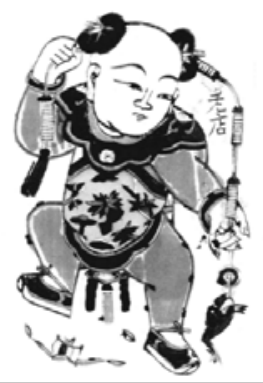

Fig. 13. Liu Hai is teasing the golden toad; Size: $20 \mathrm{~cm} \times 24 \mathrm{~cm}$.

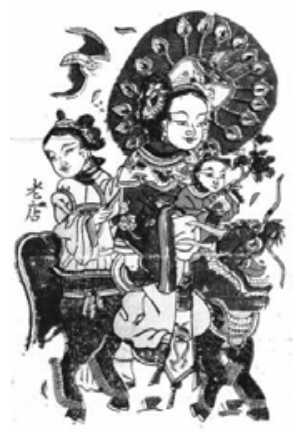

Fig. 14. Kylin is sending a child; Size: $44 \mathrm{~cm} \times 26 \mathrm{~cm}$.

\section{B. Composition Features of Chinese New Year Pictures in Zhuxianzhen}

Zhuxianzhen woodblock New Year Pictures have balanced symmetry, theme strengthening and integrality thinking of composition, in composition, pay attention to the beauty of being large and full. Zhuxianzhen woodblock New Year Picture inherits the outstanding artistic composition technique of ancient China and forms a unique style after inheriting and innovating by the heirs. The picture of the whole image is full and tight, almost no blank, can make the main figure clear, the main character prominent, especially the cooker picture, has the balanced symmetrical pattern decoration lasting appeal. The artist adopts the "scattered point perspective" which is commonly used in Chinese ink picture, which is that each picture can be clearly presented in the picture and serve for the subject, so that the picture looks clearer.

1)The composition with symmetric equilibrium and enhanced subject: In the wooden New year's pictures of
Zhuxianzhen, the images of the whole god of heaven and earth and the God of Kitchen (kitchen god, Shennong Tianzu, God of cattle, God of Horse, etc.) are generally in the form of symmetrical equilibrium and the main body is strengthened in the form of composition, in terms of the number of characters, The central axisymmetric distribution is arranged and distributed, which has the characteristics of stability, equilibrium and gravity. In the size of the characters in the use of the main characters large subordinate small figure composition and the important figures are at the center of the picture, and the figures occupy a large picture, and there will be some small figures, animals, plants or buildings around the main characters. The whole picture has the main body prominent, the primary and secondary distinct, the false reality is born, the picture has the decorative aesthetic feeling, "Fig. 15, Fig. 16 and Fig. 17".

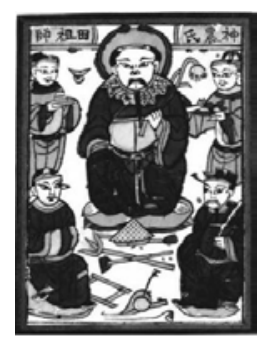

Fig. 15. Shennongshi Tianzu; Size: $23 \mathrm{~cm} \times 16 \mathrm{~cm}$.

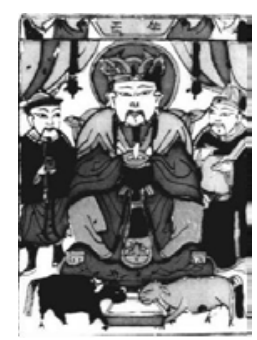

Fig. 16. King of Cattle; Size: $23 \mathrm{~cm} \times 16 \mathrm{~cm}$.

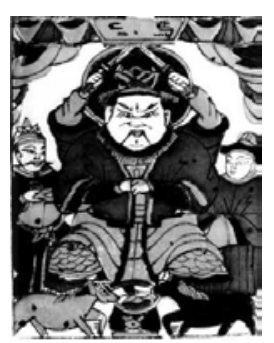

Fig. 17. King of Horse; Size: $23 \mathrm{~cm} \times 16 \mathrm{~cm}$.

2) Integrative thinking composition: Qiu Zihua in his "Oriental Aesthetics" (Vol.) has a discussion on integrality thinking, which holds that integrative thinking is an important feature of primitive thinking and a mode of thinking in which primitive people understand and grasp objects. The integrality thinking mode of Zhuxianzhen woodcut New Year Pictures can be divided into three aspects: space integrality thinking, image integrality thinking, time integrality thinking. First, in space, the principle of "scattered point perspective" is used for picture composition. Multi-level, multi-angle, spatial repetition 
and overlapping techniques are used to arrange the contents of the New Year Pictures, in which there are many immortals in the thousands of hands of Quan Yin. The image of immortals takes a large proportion of the middle image, followed by the surrounding image of the composition of the technique, in the picture, the spirit is complete, and the space posture is complete, "Fig. 18". Second, the image of the characters in the picture mostly adopts the law of "frontal law". The style of horse-riding New Year Pictures is mostly flank, the eyes of characters, shoulder are positive, the waist below is the positive side of the integrity of the thinking composition, and the same is true of other New Year pictures, "Fig. 19". Third, Zhuxianzhen woodblock New Year Pictures use panoramic expression techniques to show people's expectation of life. In the three Niang education children's New Year Pictures, the New Year pictures depict children playing on the side, and the scene where three Niangs teach their children to study hard, as well as the scene of the Child repay three Niang after taking the Merit and fame, this time on the integrity of the thinking characteristics often appear in Zhuxianzhen woodblock New Year picture, "Fig. 20".

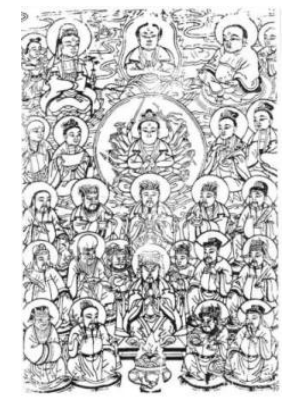

Fig. 18. Guanyin with thousands of Hands; Size: $110 \mathrm{~cm} \times 60 \mathrm{~cm}$.

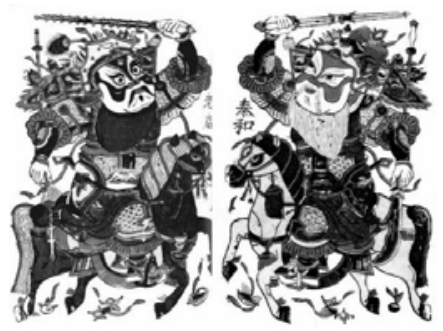

Fig. 19. Lighting Taoist and Zhao Gongming; Size: $34 \mathrm{~cm} \times 24 \mathrm{~cm}$.

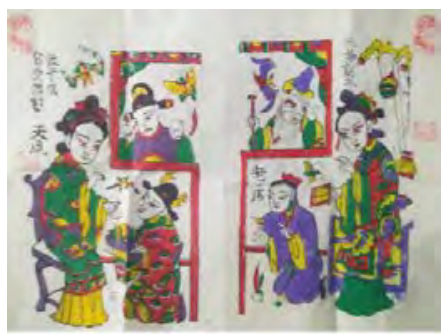

Fig. 20. Sanniang is educating a child; Size: $36 \mathrm{~cm} \times 26 \mathrm{~cm}$.

\section{Color Features of Woodblock New Year Pictures in Zhuxianzhen}

The woodblock New year Pictures of Zhu Xian Zhen make good use of warm colors, and the characters are dressed in three colors, namely, wood red, bronze green, and sunflower, which apply the colors of secular life to the religious colors of deity worship, For example, in the Han Shan, Shi De two people of "Hehe Two Immortals" they were found wearing purple robes and green robes respectively, "Fig. 21", Kitchen grandfather wore red robes and Kitchen grandmother in green robes and so on. One of the features of the character's facial drawing with Guang Dan's eyelids is to make the characters look more spiritual and generous, such as the New Year characters Qin Qiong, Wei Chi Gong, Zhao Kuangyin, Yang Gun, Chai King in the "Chai Wang Pushing A Cart", and so on, "Fig. 22".

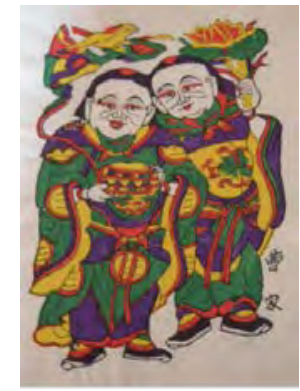

Fig. 21. Hehe two immortals; Size: $36 \mathrm{~cm} \times 26 \mathrm{~cm}$.

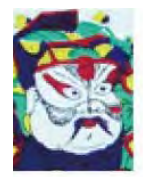
Lighting Taoist and Zhao
Gongming

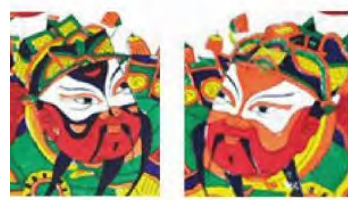

Whip under step

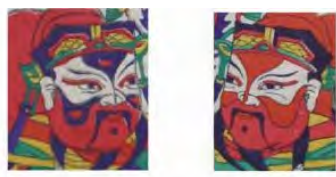

General Wearing-Robe

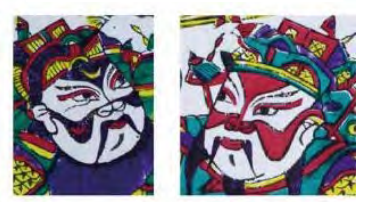

Whip over horse
Fig. 22. Analysis of faces of figures.

In New Year Pictures, different characters and different costumes are distinguished by different color blocks, and the meanings of different colors are also different, red as the main color of the New year picture is the expression of celebration, happy atmosphere, purple color of the New Year picture has a mysterious intuitive feelings, banishing evil spirits into happiness is the moral of such New Year Pictures. After the tone of the New Year picture is set, the small color block next to it uses its complementary or contrasting colors to print, thus playing a coordinated and durable effect. 


\section{A COMPARISON BETWEEN THE NEW YEAR PiCTURES OF ZHUXIANZHEN AND THOSE OF OTHER PLACES}

\section{A. Analysis on the Common Character of the New Year Pictures of Zhuxianzhen and Other New Year Pictures}

In a broad sense, the pictures of Zhuxianzhen woodblock New Year pictures are roughly the same as those of other New year's pictures, in the book "Chinese Folk Art" by Mr. Sun Jianjun, it has been written that among all kinds of wood-plate New year's pictures with different themes, the wood-plate pictures of banding away evil spirits are the oldest subjects, the wood-plate New Year pictures of incorporating happiness to welcome good fortune are the most popular theme; Festive decoration is the most widely used theme in woodcut New Year pictures, and life custom is the most common theme of woodcut New Year pictures. Different themes can be pasted according to different occasions, reflecting the practical functions of folk New Year pictures. The style of woodcut New Year pictures is about the same, mainly include the following specifications, such as: Tribute pad, Zhongtang, Contrast screen, Door pad, Door-god, Doorman, Idol, Love picture and so on. The archetypes and the stories behind them are the same, for example, Qin Qiong, Wei Qigong, Zhong Kui, Wu Zidenko and other archetypes also appeared in other New Year pictures

The creation of traditional woodcut New Year pictures in various parts of China is closely related to folk beliefs. The design of New Year pictures pays great attention to the moral meaning of their own designs, which often rely on ingenious composition, colorful colors, and profound cultural connotations to put people's faith in what they believe in something with a good moral is displayed. Zhuxianzhen woodcut New Year pictures and other wood-plate New Year pictures are often used to convey the auspicious meaning of New Year pictures by means of homophony, metaphor, and other techniques. The auspicious birds, animals and characters used in the New Year pictures are combined into beautiful patterns, lace or pictures through specific arrangement to incorporate auspicious and banishing evil.

Zhuxianzhen woodblock New Year Pictures and other New Year Pictures, in terms of practical functions, have the same workmanship. It can be concluded that the practical functions of New Year pictures include two aspects: one is to exorcise evil spirits and incorporate auspicious, and the other is to decorate and beautify the environment. When it comes to the Spring Festival, people often put different kinds of New year pictures in different positions in their homes, in order to get the life expectation of praying for their families to live a long and healthy life, everything goes well, they are promoted to make a fortune, and drive away evil spirits from their homes.

\section{B. Analysis on the Character of the New Year Pictures of Zhuxianzhen and Other New Year Pictures}

From the origin of civilization, Chinese civilization presents the characteristics of diversity. According to the regional division, Chinese civilization can be divided into different types. In the characteristics of regional folklore art, uniqueness is the most important. In many provinces of our country, there are New Year pictures with local characteristics. By using the method of investigation and comparison, the comparative analysis of the new year pictures of Zhuxianzhen and other New Year pictures shows that: there are some differences between Zhuxianzhen New year Pictures and other woodblock New Year pictures in the creative techniques, production techniques, composition techniques and color application of the New year Pictures. It can be obtained from the analysis below that woodcut New Year pictures are influenced by geographical conditions, humanistic environment, customs and habits, historical circumstances and traditional aesthetic habits, and the style characteristics of woodblock New Year Pictures in different places are unique, "Table I".

TABLE I. ANAlysis OF THE CHARACTERISTICS OF NEW YEAR PICTURES IN DifFERENT PlaCES

\begin{tabular}{|l|l|l|l|}
\hline & \multicolumn{1}{|c|}{ School } & \multicolumn{1}{|c|}{ Region } & \multicolumn{1}{|c|}{ Features } \\
\hline Southern school & Taohuawu New Year Picture & Suzhou & $\begin{array}{l}\text { The composition is symmetrical and full, the color is gorgeous, and the } \\
\text { happy atmosphere is often dominated by purplish red }\end{array}$ \\
\hline Northern school & Yangliuqing New Year Picture & Tianjin & $\begin{array}{l}\text { Elegant and delicate, the modeling tends to be realistic, the color is soft, } \\
\text { the production is exquisite }\end{array}$ \\
\hline & Zhuxianzhen New Year Pictures & Henan & Exaggeration and coarseness, simple style of picture \\
\hline & Yang Jiabu New Year Pictures & Shandong & Vigorous and bright, simple and elegant, bold and exaggerated technique \\
\hline & Wuqiang New Year Pictures & Hebei & $\begin{array}{l}\text { Shape for five short body, thick lines crazy, festival vulgar characteristics } \\
\text { of the strong }\end{array}$ \\
\hline Southwest school & Fengxiang New Year Pictures & Shaanxi & $\begin{array}{l}\text { Rough and exaggerated style, color bulk fill, mainly orange, green, peach } \\
\text { red }\end{array}$ \\
\hline & LiangPing New Year pictures & $\begin{array}{l}\text { Bright and colorful, divided into red goods, black goods two categories, } \\
\text { picture strong }\end{array}$ \\
\hline
\end{tabular}

1) Color personality: Zhuxianzhen, located in Kaifeng City, Henan Province, belongs to the Central Plains culture, which, after thousands of years of historical precipitation and evolution, has become the backbone and foundation of Chinese traditional folk culture. According to Wan Xiuhua, heir to Cao Jiadians wooden New Year picture in Zhuxianzhen, according to the regional division, the woodblock New Year picture can be divided into five parts: central, west, south, north and east. The Kaifeng Zhuxianzhen woodblock New Year picture is a woodblock New Year picture in the Central Plains. People in the Central Plains advocated Purple Emperor in ancient times. Therefore, Zhuxianzhen woodcut New Year picture is good at using purple, which is relatively rare in other woodblock New Year pictures. "West" refers to Mianzhu 
wooden New Year Pictures in Southwest China. Mianzhu New Year pictures are good at using colored pictures and are divided into black and red. By means of comparison, the colors are mostly matched by intermediate colors and compound colors. Buddha green, peach red, grass green, and scarlet are its main colors, gold yellow, sky blue are secondary color. Jiangsu Taohuawu woodcut New Year pictures belong to the southern wood-plate New Year pictures, influenced by the local people preferences. The Taohuawu New Year pictures are refined and refined in style, and the colors of the Taohuawu New Year pictures are mostly in blocks of bright red, peach red, yellow, green, purple (or blue, Generally using purple without blue, with blue without purple) and light ink constitute the basic tone. Shaanxi New year' Pictures belong to the Northwest New Year Pictures. They are mainly concentrated in Hanzhong, Fengxiang, Shenmu, Pucheng, Changan and other places. Among them, Fengxiang New Year pictures are influenced by the local mountains and trees. The images are often mainly orange, green and peach red, and yellow is more transparent, slightly show tender. "East" refers to Yangjiabu woodcut New Year Pictures in Shandong, which are good at using blue because of the proximity of Shandong to the sea.

2) Stylistic personality: The composition of the wood plates of Zhu Xian Town is full and balanced, and the lines are rough and strong. In the Qing Dynasty, the pictures of the wood plates of the town of Zhuxianzhen are full and close, and almost rarely appear blank, and the whole picture has the characteristics of the upper part is empty and the lower part is real, the composition has the main body and the secondary, the main object is prominent, the scene figure arrangement is delicate, the whole picture is reasonable and not complicated. The pattern uses even, symmetrical composition technique, the decoration effect is extremely strong, has the rich local tone and the pure folk tradition style.

Yangliuqing wooden New Year pictures, which belong to the North School of picture, have a rigorous style of picture and are influenced by literati pictures. They adopt more realistic and meaningful creative techniques. The scenes are lively and vivid, with precise and chic production, soft colors and colorful colors, and the lines are fluent and refreshing which have a strong court interest and civic interest and a very strong flavor of life.

3) Process personality: In the printing technique, Zhuxianzhen woodblock New Year pictures have a very unique color processing technology and printing technology, which retained the traditional overprint ancient method, almost no hand-drawn, and very few rendering of the pictures. Through this special technology, the color of the New Year Pictures is retro, thick and plain, so that Zhuxianzhen woodcut New Year pictures have bright and not vulgar, calm and not dark features. Through this special technology, the color of the New Year Pictures is retro, thick and plain, so that Zhuxianzhen woodcut New Year pictures have bright and not vulgar, calm and not dark features. And Zhuxianzhen woodcut New Year pictures adopt the traditional method to not decolor, not fade, also can be anti-corrosive, durable, and with long storage time and more delicate color.
The manufacturing process of Yangliuqing woodblock New Year pictures is very sophisticated. Most of them use the method of half-printing and half-engraving. The plank cover printing is combined with manual color picture. First, based on the overprint of the engraved version of the picture, and then in the later stage, it will have to be hand-painted. Manual picture requires a great deal of effort and manpower, which makes the picture look rich and delicate. Sichuan Mianzhu woodblock New Year Picture is famous for color picture and line version in Mianzhu New year pictures play an outline role, the final completion needs to be completed by hand.

\section{Cultural CONNOTATION AND RELigious IMPLICATION OF WOODBLOCK NEW YEAR PICTURES IN ZHUXIANZHEN}

"Shangshu - Yi Ji" once recorded: "Drawing a variety of patterns on clothes in a variety of colors". The view of five colors has a profound influence on the color aesthetics of Chinese people from ancient times to now. The color theory of Confucianism and Taoism has laid a theoretical foundation for the traditional color aesthetics. The ideological and theoretical basis of the five colors system is the theory of yin yang five elements and the theory of yin yang five elements that everything in the world is composed of gold wood water fire and earth. The five colors corresponding to species are five colors. The color of Zhuxianzhen woodblock New Year picture is used for reference in the traditional five color system. The commonly used colors are ink black, red, locust yellow, bronze green, sunflower purple, wood red. The contrasting color blocks are divided by ink lines, and the colors are gorgeous without losing their seriousness.

According to Wang Shucun's description of the origin of religion in "the History of Chinese New year Pictures", it can be seen that the origin of the New Year pictures of door gods and Kitchen gods can be traced back to the earliest records of the Yin and Shang dynasties. It can be seen that people in the Yin and Shang Dynasty has produced the germination of religious belief. Zhuxianzhen woodblock New Year pictures were originally made up of mythical stories because people lacked the cognition of natural phenomena and were full of reverence and worship for nature and subjectively planned all things to different deities. New Year pictures of door god and kitchen god in Zhuxianzhen woodcut New Year picture are two important themes of New Year pictures; the main religious function is to bless the family and all things. Second, apart from the subject matter, New Year pictures in different themes, has a strong spiritual utility. Because of the backwardness of science and technology at that time, people could not explain the natural and man-made disasters and geological disasters, and the farmers who depended on heaven for food could not predict the harvest of their crops, so people longed for the protection of gods and often worshipped all kinds of agricultural gods, for example, the god of the field, Circle god, who expect a good harvest of grain and six livestock prosperity. Thirdly, people yearn for reproduction, life and the pursuit of auspicious and happy life. Reproductive worship is an ancient religious belief. In the folk art of the Yellow River Basin, there are many fish body dolls, fish lotus born children, Pomegranate open hundred son, Kirin send son and other 
artistic images that symbolize the reproduction of descendants. Folk have a lot of metaphors and auspicious artistic modeling, for example the "kylin sending child" in Zhuxianzhen woodblock New Year Pictures has this meaning.

\section{CONCLUSION}

Zhuxianzhen woodcut New Year picture is the first batch of folk art to be selected into the list of China's intangible materialized heritage. It originates early, and the number of New Year pictures is numerous and has profound cultural connotations. Compared with other New Year pictures, Zhuxianzhen woodblock New Year Picture style is unique, full of composition, rough lines, exaggerated modeling, and strong local flavor in the north. $\mathrm{Lu}$ Xun once wrote: "among Zhuxianzhen woodcut pictures, for the old picture, we will know the story, and then look at the picture; for the new picture, we have to first look at the picture and then know the story. There are things to look and to talk in these pictures, stories in them, to make not feel tired. Most of Zhuxianzhen woodcut pictures have stories". In their works, Zhuxianzhen woodblock artists pay attention to the expressiveness, connotation and creativity of the New Year pictures. Image language has the characteristics of Central Plains, so it deserves people's attention, protection and further research.

\section{REFERENCES}

[1] Tang Yi. Folk craftsmanship that can’t be unknown in one's life [M]. Beijing: enterprise Management Press, 2013.5. (in Chinese)

[2] Tao Siyan. Folk Art [M]. Nanjing: Nanjing Press, 2013.8. (in Chinese)

[3] Zhang Jizhong. Flowers of the East: Zhuxianzhen woodblock New year Pictures [M]. Beijing: solidarity Press, 2016.12. (in Chinese)

[4] Qiu Zihua. Oriental Aesthetics (Vol.1) [M]. Beijing: The Commercial Press, 2003. (in Chinese)

[5] Wang Shucun. History of Chinese New year Pictures [M]. Beijing: Beijing Arts and Crafts Press, 2002.6. (in Chinese)

[6] Wang Shucun. History of Chinese New year Pictures [M]. Tianjin: Tianjin people's Art Publishing House, 2005.1. (in Chinese)

[7] Feng Jicai. Chinese Wood New year Pictures Integration. Zhuxianzhen Volume [M]. Beijing: Zhonghua Book Company, 2006. (in Chinese)

[8] Zuo Hanzhong. Chinese Folk Art Modeling [M]. Changsha: Hunan Fine Arts Press, 2006. (in Chinese)

[9] Sun Jianjun. Chinese Folk Art [M]. Shanghai: Shanghai Pictorial Press, 2006. (in Chinese)

[10] Cui Ying. Study on decorative characteristics and Cultural value of woodblock New year Pictures in Zhuxianzhen [D]. Master thesis of Tianjin University of Science and Technology, 2016.1. (in Chinese)

[11] Wang Liujing. On Zhuxianzhen Wood New year Picture and graphic Design [D]. Master thesis of Shaanxi normal University, 2015.5. (in Chinese)

[12] Chen Jiao, Huang Shihui, Wu Yan. A study on the Image of large and small Sea banners of Jiang Hua' Yao Statue picture in Qing Dynasty. [J] Decoration, 2017, (11): 92-l 95. (in Chinese)

[13] Yu Wenwei, Zhou Wuzhong. View of five colors and Chinese traditional phenomenon of Color use [J]. A hundred schools of art, 2007, (5): $138 \sim 140$. (in Chinese) 